\title{
Gastric Inhibitory Polypeptide (GIP) and Insulin in Obesity: II. Reversal of Increased Response to Stimulation by Starvation or Food Restriction
}

\author{
B. Willms ${ }^{1}$, R. Ebert, and W. Creutzfeldt \\ Division of Gastroenterology and Metabolism, Department of Medicine, University of Göttingen, FRG
}

Summary. The response of serum immunoreactive gastric inhibitory polypeptide (IR-GIP) and immunoreactive insulin (IRI) to a liquid mixed test meal, glucose or fat has been examined in obese subjects before and after starvation or reduced caloric intake (800 calories). Basal serum levels of IR-GIP increased significantly during starvation of obese persons and remained elevated over the whole starvation period while basal serum IRI levels decreased. The exaggerated IR-GIP response of obese subjects with normal or pathological glucose tolerance to a test meal and of obese subjects with glucose intolerance to $100 \mathrm{~g}$ glucose ingestion decreased significantly after starvation or food restriction. Simultaneously, the serum IRI response decreased. The exaggerated IR-GIP response of obese subjects to oral triglycerides which did not affect serum IRI or glucose levels was also significantly decreased after food restriction. The IR-GIP response of obese subjects to a test meal was already reduced after 5 days of food restriction together with an improved glucose tolerance. At this stage the IRI response was unchanged. After weight reduction in obese subjects there was a significant decrease of the IRI response to oral but not to intravenous glucose, while the glucose response decreased irrespectively of the mode of glucose administration. The IR-GIP response decreased only after oral glucose. The data are compatible with the hypothesis that the exaggerated IR-GIP response of obese subjects to oral glucose or fat load is secondary to the increased food intake and that changes in IRI response to oral glucose are related to changes in IR-GIP response.

\footnotetext{
1 Fachklinik für Diabetes und Stoffwechselkrankheiten, Bad Lauterberg im Harz, FRG
}

Key words: GIP release, insulin release, obesity, glucose intolerance, starvation, food restriction, weight reduction, oral glucose load, test meal, triglyceride ingestion.

An exaggerated response of GIP has been observed in obese subjects following ingestion of a test meal, glucose, or fat [13]. From this has been concluded that an overactive entero-insular axis participates in the hyperinsulinaemia of obesity. The aim of the present study was to examine whether the increased GIP release of obesity is reversed by starvation or reduced caloric intake and whether this reversal is accompanied by a decrease of serum insulin levels. Some of the results have been presented previously in a preliminary form [14].

\section{Materials and Methods}

\section{a) Subjects}

The studies were carried out on 147 obese subjects (42 male, 105 female). Informed consent was obtained from all subjects. The pertinent clinical characteristics of each group are shown in Table 1. All subjects studied exceeded $130 \%$ ideal body weight [16] before onset of the study. The subjects were divided into two groups according to the glucose response to the test meal or to a $100 \mathrm{~g}$ glucose load. Subjects with normal oral glucose tolerance (nOGT) had a 60 plus 120 min sum of blood glucose levels below $290 \mathrm{mg} / 100 \mathrm{ml}$, subjects with pathological glucose tolerance (pOGT) a sum of above 
Table 1. Clinical data of the subjects studied (mean \pm SEM). nOGT $=$ normal oral glucose tolerance; pOGT $=$ pathological oral glucose tolerance

\begin{tabular}{|c|c|c|c|c|c|c|c|}
\hline & \multirow[t]{2}{*}{$\mathrm{n}$} & \multicolumn{2}{|l|}{ Sex } & \multirow[t]{2}{*}{ Age } & \multicolumn{2}{|c|}{$\%$ Ideal body weight at } & \multirow{2}{*}{$\begin{array}{l}\text { Weight loss } \\
(\mathrm{kg})\end{array}$} \\
\hline & & Males & Females & & 1. test & 2. test & \\
\hline \multicolumn{8}{|l|}{ Protocol 1: } \\
\hline \multicolumn{8}{|l|}{$\begin{array}{l}\text { Test meal, starvation } \\
\text { for } 21 \text { days }\end{array}$} \\
\hline obese (nOGT) & 19 & 6 & 13 & $\begin{array}{l}42 \pm 4.5 \\
\text { (range 19-51) }\end{array}$ & $176 \pm 12.9$ & $150 \pm 9.4$ & $10 \pm 1.6$ \\
\hline obese (pOGT) & 31 & 5 & 26 & $\begin{array}{l}41 \pm 5.9 \\
\text { (range 25-56) }\end{array}$ & $180 \pm 13.4$ & $157 \pm 14.0$ & $11 \pm 1.5$ \\
\hline \multicolumn{8}{|l|}{ Protocol 2: } \\
\hline \multicolumn{8}{|l|}{$\begin{array}{l}\text { Glucose load, } \\
\text { starvation for } 21 \text { days }\end{array}$} \\
\hline obese (POGT) & 19 & 3 & 16 & $\begin{array}{l}40 \pm 6.3 \\
\text { (range 25-51) }\end{array}$ & $162 \pm 9.5$ & $146 \pm 6.8$ & $12 \pm 1.3$ \\
\hline \multicolumn{8}{|l|}{ Protocol 3: } \\
\hline \multicolumn{8}{|l|}{$\begin{array}{l}\text { Test meal, food } \\
\text { restriction }(800 \mathrm{cal}) \\
\text { for } 21 \text { days }\end{array}$} \\
\hline obese (nOGT) & 7 & 3 & 4 & $\begin{array}{l}45 \pm 5.3 \\
\text { (range 32-54) }\end{array}$ & $156 \pm 8.6$ & $133 \pm 5.4$ & $7 \pm 1.0$ \\
\hline obese (pOGT) & 26 & 12 & 14 & $\begin{array}{l}39 \pm 7.0 \\
\text { (range 22-51) }\end{array}$ & $170 \pm 6.4$ & $152 \pm 6.0$ & $9 \pm 1.2$ \\
\hline \multicolumn{8}{|l|}{$\begin{array}{l}\text { Protocol } 4 \text { : } \\
\text { Fat load, food } \\
\text { restriction }(800 \mathrm{cal}) \\
\text { for } 21 \text { days }\end{array}$} \\
\hline obese (nOGT) & 7 & 2 & 5 & $\begin{array}{l}37 \pm 5.1 \\
\text { (range 27-44) }\end{array}$ & $146 \pm 5.0$ & $131 \pm 3.6$ & $7 \pm 0.7$ \\
\hline obese (pOGT) & 10 & 4 & 6 & $\begin{array}{l}41 \pm 5.5 \\
\text { (range 29-55) }\end{array}$ & $177 \pm 9.1$ & $154 \pm 5.4$ & $8 \pm 1.0$ \\
\hline \multicolumn{8}{|l|}{ Protocol 5: } \\
\hline \multicolumn{8}{|l|}{$\begin{array}{l}\text { Test meal, food } \\
\text { restriction }(800 \mathrm{cal}) \\
\text { for } 5 \text { days }(1)\end{array}$} \\
\hline $\begin{array}{l}\text { and subsequent starvation } \\
\text { for } 21 \text { days (2) }\end{array}$ & & & & & & & $\begin{array}{l}\text { (1) } 2 \pm 0.4 \\
\text { (2) } 13 \pm 2.1\end{array}$ \\
\hline obese (pOGT) & 14 & 4 & 10 & $\begin{array}{l}36 \pm 6.1 \\
\text { (range } 25-49)\end{array}$ & $169 \pm 10.3$ & $127 \pm 6.9$ & $15 \pm 1.4$ \\
\hline \multirow{2}{*}{\multicolumn{8}{|c|}{$\begin{array}{l}\text { Protocol } 6 \text { : } \\
\text { Oral and intravenous } \\
\text { glucose load, food } \\
\text { restriction for } 14 \text { days }\end{array}$}} \\
\hline & & & & & & & \\
\hline $\begin{array}{l}\text { restriction for } 14 \text { days } \\
\text { obese (pOGT) }\end{array}$ & 9 & 2 & 7 & $\begin{array}{l}35 \pm 4.1 \\
\text { (range 26-47) }\end{array}$ & $167 \pm 8.0$ & $155 \pm 9.1$ & $5 \pm 0.7$ \\
\hline
\end{tabular}

$310 \mathrm{mg} / 100 \mathrm{ml} \mathrm{[15]}$. The correlation coefficient of the glucose response between $100 \mathrm{~g}$ glucose load and the test meal in 36 subjects was $r=0.8036$. Subjects with fasting blood glucose levels above $130 \mathrm{mg} /$ $100 \mathrm{ml}$ were omitted from this study. Except for 12 patients, the obese subjects were hospitalised for weight reduction and the tests performed under clinical observations. Before starvation or decreased caloric intake all subjects studied had been on an unrestricted diet, containing over $200 \mathrm{~g}$ carbohydrate per day.

\section{b) Protocols}

1. Test Meal before and after Starvation: After an overnight fast an indwelling cannula was inserted into an antecubital vein and kept patent by slow infusion of saline $(0.154 \mathrm{~mol} / \mathrm{l})$. Three fasting blood samples were drawn with further samples taken at $15,30,45$, $60,120,150,180,210,240,270$ and 300 min after ingestion of the test meal. The test meal contained 1031 Calories and consisted of $18 \mathrm{~g}$ glucose, $14 \mathrm{~g}$ maltose, 12 g maltotriose, 52 g lactose, 56 g oligosac- 
charides, $100 \mathrm{ml}$ cream (containing 30\% fat), and $36 \mathrm{~g}$ milk protein [17]. After taking basal samples, $550 \mathrm{ml}$ of this mixed formula was ingested within $10 \mathrm{~min}$. Blood samples obtained were immediately placed on ice and centrifuged at $4^{\circ} \mathrm{C}$. Five aliquots of each serum sample were frozen and stored at $-20^{\circ} \mathrm{C}$ until assayed. After this test the 50 obese subjects underwent total caloric restriction for 21 days. They were asked to drink $2000-3000 \mathrm{ml}$ fluid daily in the form of mineral water and not to change their physical activity. Mean weight loss after 3 weeks starvation was $10.8 \pm 1.9 \mathrm{~kg}$. At this stage only 6 patients had reached their ideal body weight, the majority being still grossly obese. The patients were refed with increasing amounts of calories for 3 days (200, $800,1400 \mathrm{Cal}$.). The test meal study was repeated after an overnight fast on the 4 th day.

2. Oral Glucose Load before and after Starvation: Nineteen obese subjects with glucose intolerance ingested $100 \mathrm{~g}$ glucose, dissolved in $300 \mathrm{ml}$ water, before and after starvation. The other test conditions were as described in protocol 1 , except that blood samples were obtained for only $240 \mathrm{~min}$ after ingestion of glucose. Mean weight reduction was $11.6 \pm$ $1.5 \mathrm{~kg}$. No subjects reached the ideal body weight.

\section{Test Meal before and after Food Restriction: After} a test meal study as described in protocol 133 obese subjects were placed on a hypocaloric diet for 21 days. This diet containd 800 Cal. per day ( $42 \%$ carbohydrate, $16 \%$ protein, $42 \%$ fat). Before the second test the obese subjects received an $1800 \mathrm{Cal}$. diet for 4 days. Mean weight loss in this group was $8.3 \pm$ $1.4 \mathrm{~kg}$.

4. Oral Triglycerides before and after Food Restriction: Seventeen obese subjects ingested $150 \mathrm{ml}$ of a suspension of corn oil (Lipomul ${ }^{(R)}$, Upjohn Company, Kalamazoo), corresponding to $100 \mathrm{~g}$ triglycerides before and after a hypocaloric diet for 21 days as described in protocol 3. Mean weight loss was 7.5 $\pm 1.0 \mathrm{~kg}$.

\section{Test Meal before and following Food Restriction and Subsequent Starvation: Fourteen obese subjects with glucose intolerance were placed on a hypocaloric diet $(800 \mathrm{Cal}$.) for 5 days followed by a period of total caloric restriction for 21 days. The test meal was given before and immediately after the period of hypocaloric diet and at the end of the star- vation period. The patients lost $2.4 \pm 0.4 \mathrm{~kg}$ during caloric restriction and $12.7 \pm 2.1 \mathrm{~kg}$ during starva- tion.}

6. Comparison of Oral and Intravenous Glucose Load before and after Food Restriction: In 9 grossly obese subjects (mean overweight $+67.4 \%$ ideal body weight) with glucose intolerance, both an oral and an intravenous glucose load were performed in randomized sequence before and after 14 days of an $800 \mathrm{Cal}$. diet. The subjects ingested $100 \mathrm{~g}$ glucose or received intravenously $1.1 \mathrm{~g} / \mathrm{kg}$ body weight glucose over $90 \mathrm{~min}$. Mean weight loss was $5.2 \pm 0.7 \mathrm{~kg}$. The tests were repeated after a further week of unrestricted food intake. During this week the weight of the test subjects did not change by more than $1.2 \pm$ $0.5 \mathrm{~kg}$. Blood sample during both tests were obtained over a period of $180 \mathrm{~min}$ after the glucose load.

\section{c) Chemical Analyses}

Serum glucose was measured in duplicate on each sample by the glucose oxidase method immediately after separating the serum. Immunoreactive insulin (IRI) and immunoreactive GIP (IR-GIP) were determined in duplicate on each sample within four weeks after the test. Serum IRI was measured using human insulin as standard [18]. Serum IR-GIP was measured by the method of Kuzio et al. [19] using GIP antibody VAN No. 8. Some minor modifications were introduced in order to obtain better reproducibility and to improve the sensitivity $[17,13]$. The GIP antiserum used in this study did not crossreact with glucagon, secretin, CCK, gut glucagon I and gastrin. Porcine GIP was used as standard. The lower limit of sensitivity varied from assay to assay ranging from 3 $\mathrm{pg}$ to $12.5 \mathrm{pg}$. Since final serum dilution in our assays is $1: 10$, the actual sensitivity for practical determination varies from 30 to $125 \mathrm{pg} / \mathrm{ml}$ of serum. The interassay coefficient of variation was $13.4 \%$ and the intra-assay one $8.3 \%$ (mean of 152 assays). According to unpublished investigations our assay measures big and little IR-GIP. Using Sephadex G-50 fine columns $(1 \times 200 \mathrm{~cm})$ alcoholic serum extracts could be separated into one peak at $7500-8500$ molecular weight ("big" GIP) and a second peak at 5000 molecular weight ("little" GIP). One hour after a glucose and also a fat load about one third of the IRGIP appeared as "big" and two thirds as "little" IRGIP.

\section{d) Statistical Analysis}

All values given in the text and in Table 2 and 3 are presented as means \pm standard deviation (SD). Results were analyzed using standard statistical methods. The two-tailed paired Student's " $t$ "-test was employed for comparison of the results before and after starvation or reduced caloric intake, respec- 

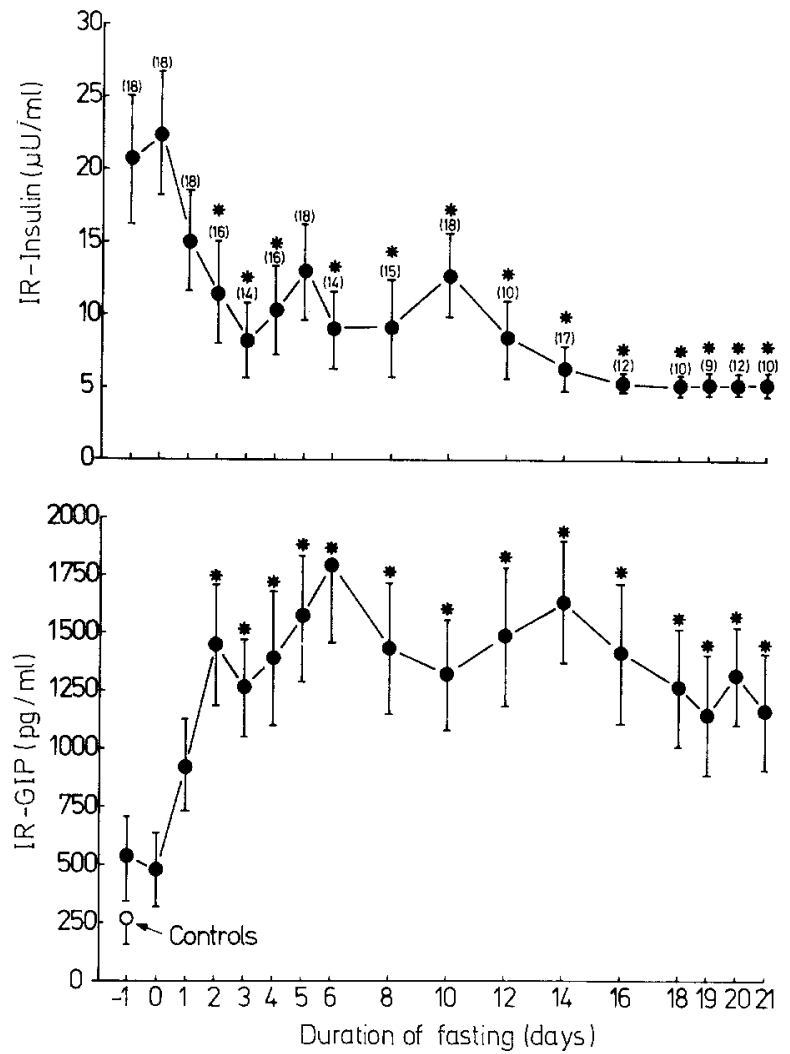

Fig. 1. Fasting serum levels of IR-GIP and IRI during total starvation of obese subjects. All values are means \pm SEM. Numbers in parentheses indicate number of patients. $*=$ significantly different from initial value. Basal IRI levels of 35 normal weight subjects were $9.4 \pm 0.2 \mu \mathrm{U} / \mathrm{ml}$

tively. Integrated responses to the test meal and the glucose or fat load for serum glucose, IRI, and IRGIP were calculated from summation of the products of the mean serum concentrations during each time period, multiplied by the number of minutes in the time period minus the product of the basal value multiplied by the total number of minutes after a test [20].

\section{Results}

\section{Basal Levels before and after Weight Reduction and during Starvation}

The basal serum levels of IR-GIP increased during starvation of obese subjects. This increase reached significance after two days. The GIP levels remained elevated over the whole starvation period of 21 days (Fig. 1). Simultaneously, serum IRI levels decreased. This decrease was significant from the second until the 21st day starvation (Fig. 1).

After starvation for 3 weeks and refeeding for 3 days the fasting levels of IR-GIP were still signifi-

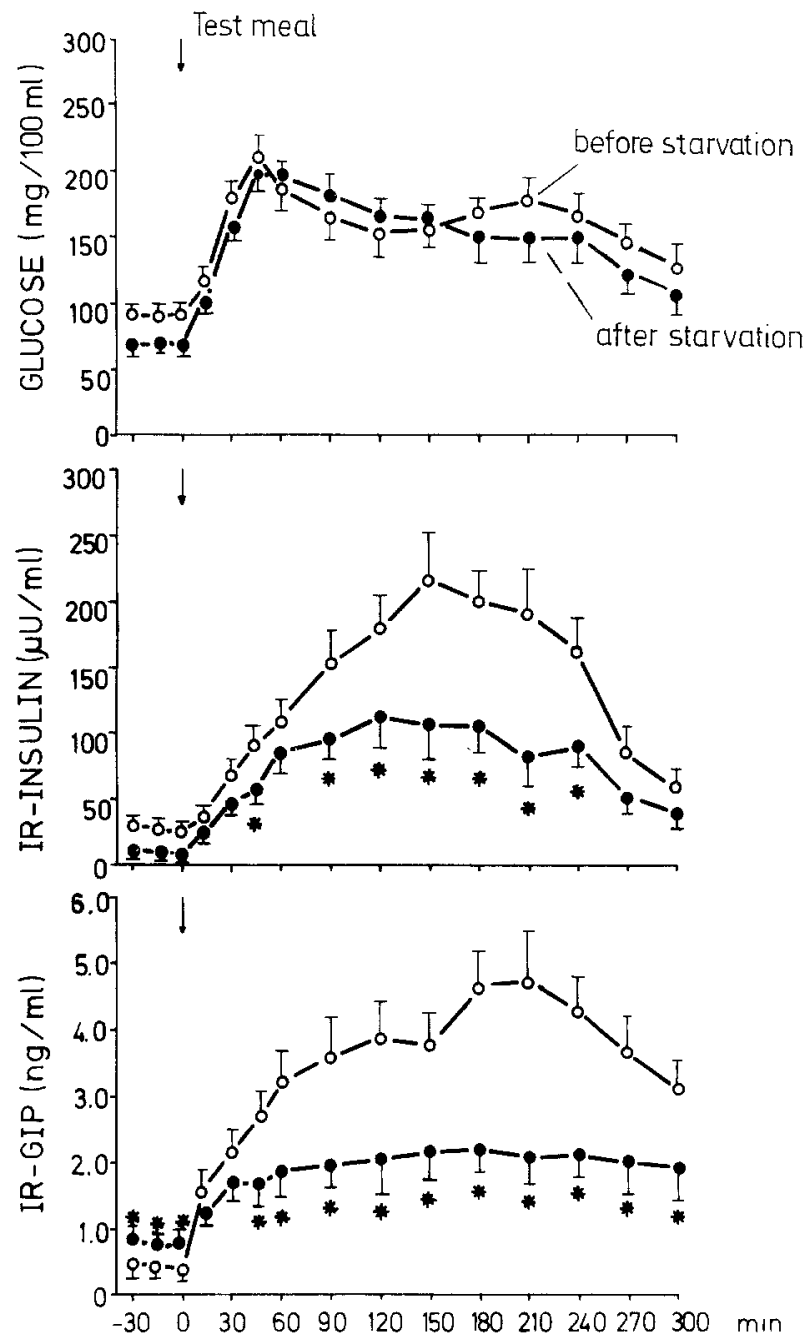

Fig. 2. Increase of serum levels of IR-GIP, IRI and glucose in 50 obese subjects before $(0-0)$ and after $(\bullet-)$ starvation for 21 days and refeeding for three days. The subjects ingested a mixed liquid test meal at $0 \mathrm{~min}$. All values are mean $\pm \mathrm{SEM}$. Significant differences between the serum levels before and after starvation are indicated $(*=p<0.02$ and less)

cantly higher and the fasting IRI levels lower than before starvation (Table 2). Also after food restriction $(800 \mathrm{cal}$.) in obese subjects for 3 weeks fasting IR-GIP levels increased and IRI levels decreased (Table 2). However the changes in this group were significant only for the serum IRI levels.

\section{Response to a Mixed Test Meal before and after Starvation (Fig. 2, Table 3)}

As illustrated in Figure 2 the exaggerated response of IR-GIP and IRI of the 50 obese patients became much smaller after starvation for 21 days and 3 days refeeding. The difference between the IR-GIP curves before and after starvation became significant after 
Table 2. Fasting serum levels of IR-GIP, IRI and glucose of obese subjects before and after starvation or food restriction (mean \pm SD). nOGT $=$ normal oral glucose tolerance; pOGT $=$ pathological oral glucose tolerance

\begin{tabular}{|c|c|c|c|c|c|c|c|}
\hline & & \multicolumn{2}{|c|}{ IR-GIP (pg/ml) } & \multicolumn{2}{|c|}{ IRI $\mu \mathrm{U} / \mathrm{ml})$} & \multicolumn{2}{|c|}{ Glucose $(\mathrm{mg} / 100 \mathrm{ml})$} \\
\hline & & Before & After & Before & After & Before & After \\
\hline \multicolumn{8}{|l|}{$\begin{array}{l}\text { 1. Starvation for } 21 \text { days } \\
\text { and } 3 \text { days refeeding }\end{array}$} \\
\hline obese subjects nOGT & 24 & $356 \pm 79$ & $812 \pm 126^{\mathrm{a}}$ & $28 \pm 3$ & $11 \pm 2^{\mathrm{a}}$ & $85 \pm 4$ & $76 \pm 4$ \\
\hline obese subjects pOGT & 50 & $447 \pm 104$ & $968 \pm 134^{\mathrm{a}}$ & $30 \pm 5$ & $17 \pm 4^{a}$ & $97 \pm 6$ & $76 \pm 5^{\mathrm{a}}$ \\
\hline \multicolumn{8}{|l|}{ 2. Food restriction for 21 days } \\
\hline obese subjects nOGT & 14 & $438 \pm 120$ & $522 \pm 118$ & $31 \pm 4$ & $9 \pm 2^{a}$ & $79 \pm 6$ & $76 \pm 5$ \\
\hline obese subjects pOGT & 36 & $472 \pm 96$ & $568 \pm 140$ & $27 \pm 4$ & $10 \pm 3^{a}$ & $95 \pm 7$ & $71 \pm 3^{a}$ \\
\hline
\end{tabular}

$\mathrm{a}=$ significant difference from initial values; $\mathrm{p}<0.02$ or less

Table 3. Integrated responses ( $180 \mathrm{~min}$ ) of serum levels of IR-GIP, IRI and glucose in obese subjects before and after starvation or food restriction. For clinical data see Table 1 (mean \pm SD) nOGT = normal oral glucose tolerance; pOGT = pathological oral glucose tolerance

\begin{tabular}{|c|c|c|c|c|}
\hline & $\mathrm{n}$ & $\begin{array}{l}\text { IR-GIP } \\
(\mathrm{ng} / \mathrm{ml} \cdot 180 \mathrm{~min})\end{array}$ & $\begin{array}{l}\text { IRI } \\
(\mathrm{mU} / \mathrm{ml} \cdot 180 \mathrm{~min})\end{array}$ & $\begin{array}{l}\text { Glucose } \\
(\mathrm{g} / 100 \mathrm{ml} \cdot 180 \mathrm{~min})\end{array}$ \\
\hline \multicolumn{5}{|l|}{ Protocol 1: } \\
\hline \multicolumn{5}{|l|}{ Test meal, starvation for 21 days } \\
\hline before starvation & & $302.0 \pm 36.47^{c}$ & $27.8 \pm 3.5]^{c}$ & $4.6 \pm 0.97^{\mathrm{a}}$ \\
\hline after starvation & & $167.1 \pm 19.4]$ & $10.5 \pm 1.4$ & $8.0 \pm 1.6$ \\
\hline pOGT & 31 & & & \\
\hline before starvation & & $621.3 \pm 81.9]^{\mathrm{d}}$ & $29.4 \pm 4.1^{c}$ & $18.3 \pm 2.7$ \\
\hline after starvation & & $151.0 \pm 20.4]$ & $12.3 \pm 1.5]$ & $15.6 \pm 1.6]^{\text {n.s. }}$ \\
\hline & & & & \\
\hline Glucose load, starvation for & & & & \\
\hline 21 days & & & & \\
\hline pOGT & 19 & & & \\
\hline before starvation & & $198.4 \pm 18.6]^{b}$ & $16.5 \pm 1.9]^{c}$ & $16.9 \pm 1.7]^{\mathrm{a}}$ \\
\hline after starvation & & $87.6 \pm 9.1\rfloor$ & $7.9 \pm 1.0^{\rfloor}$ & $11.8 \pm 1.5$ \\
\hline \multicolumn{5}{|l|}{ Protocol 3: } \\
\hline \multicolumn{5}{|l|}{ Test meal, food restriction } \\
\hline before food restriction & & $386.3 \pm 42.9]^{b}$ & $28.1 \pm 3.1]^{a}$ & $13.9 \pm 1.57 \mathrm{~ns}$ \\
\hline after food restriction & & $190.6 \pm 20.4\rfloor$ & $19.2 \pm 2.3\rfloor$ & $10.1 \pm 1.2$ \\
\hline \multicolumn{5}{|l|}{ Protocol 4: } \\
\hline $\begin{array}{l}\text { Fat load, food restriction } \\
(800 \text { cal) for } 21 \text { days }\end{array}$ & 17 & & & \\
\hline before food restriction & & $359.3 \pm 40.67^{\mathrm{b}}$ & $1.2 \pm 0.3]$ & $-0.2 \pm 0.05$ \\
\hline after food restriction & & $201.2 \pm 26.9]$ & $0.8 \pm 0.1]$ n.s. & $-0.5 \pm 0.1] \mathrm{n} . \mathrm{s}$. \\
\hline \multicolumn{5}{|c|}{ Protocol 5: } \\
\hline \multirow{2}{*}{\multicolumn{5}{|c|}{$\begin{array}{l}\text { Test meal, food restriction } \\
(800 \mathrm{cal}) \text { for } 5 \text { davs and subsequent }\end{array}$}} \\
\hline & & & & \\
\hline \multicolumn{5}{|l|}{ starvation for 21 days } \\
\hline before food restriction & & $479.2 \pm 59.3]^{c}$ & $20.4 \pm 2.6$ n.s. & $16.8 \pm 1.4]^{\mathrm{a}}$ \\
\hline after food restriction & & $259.8 \pm 36.1 \mathrm{~b}$ & $19.0 \pm 2.1$ & $10.2 \pm 1.2$ \\
\hline after subsequent starvation & & $120.2 \pm 10.9]$ & $12.0 \pm 1.5]$ & $14.9 \pm 1.6] \mathrm{n} . \mathrm{s}$. \\
\hline \multicolumn{5}{|l|}{ Protocol 6: } \\
\hline \multicolumn{5}{|l|}{ Oral and intravenous glucose } \\
\hline \multicolumn{5}{|l|}{ load, food restriction for } \\
\hline 14 days & 9 & & & \\
\hline \multicolumn{5}{|l|}{ oral glucose } \\
\hline before food restriction & & $157.0 \pm 16.8]^{b}$ & $15.6 \pm 1.8]^{\mathrm{b}}$ & $18.3 \pm 2.0]$ \\
\hline after food restriction & & $86.9 \pm 8.4$ & $7.2 \pm 1.0$ & $12.4 \pm 1.4]$ \\
\hline \multicolumn{5}{|l|}{ intravenous glucose } \\
\hline before food restriction & & $2.1 \pm 0.4 \operatorname{lns}$ & $14.4 \pm 1.6$ & $26.4 \pm 2.5]^{\mathrm{a}}$ \\
\hline after food restriction & & $1.6 \pm 0.]^{\text {n.s. }}$ & $11.7 \pm 1.5] \mathrm{n.s.}$ & $19.0 \pm 1.4]$ \\
\hline
\end{tabular}

a $<0.05 \quad$ b $<0.02 \quad$ c $<0.01 \quad$ d $<0.005$




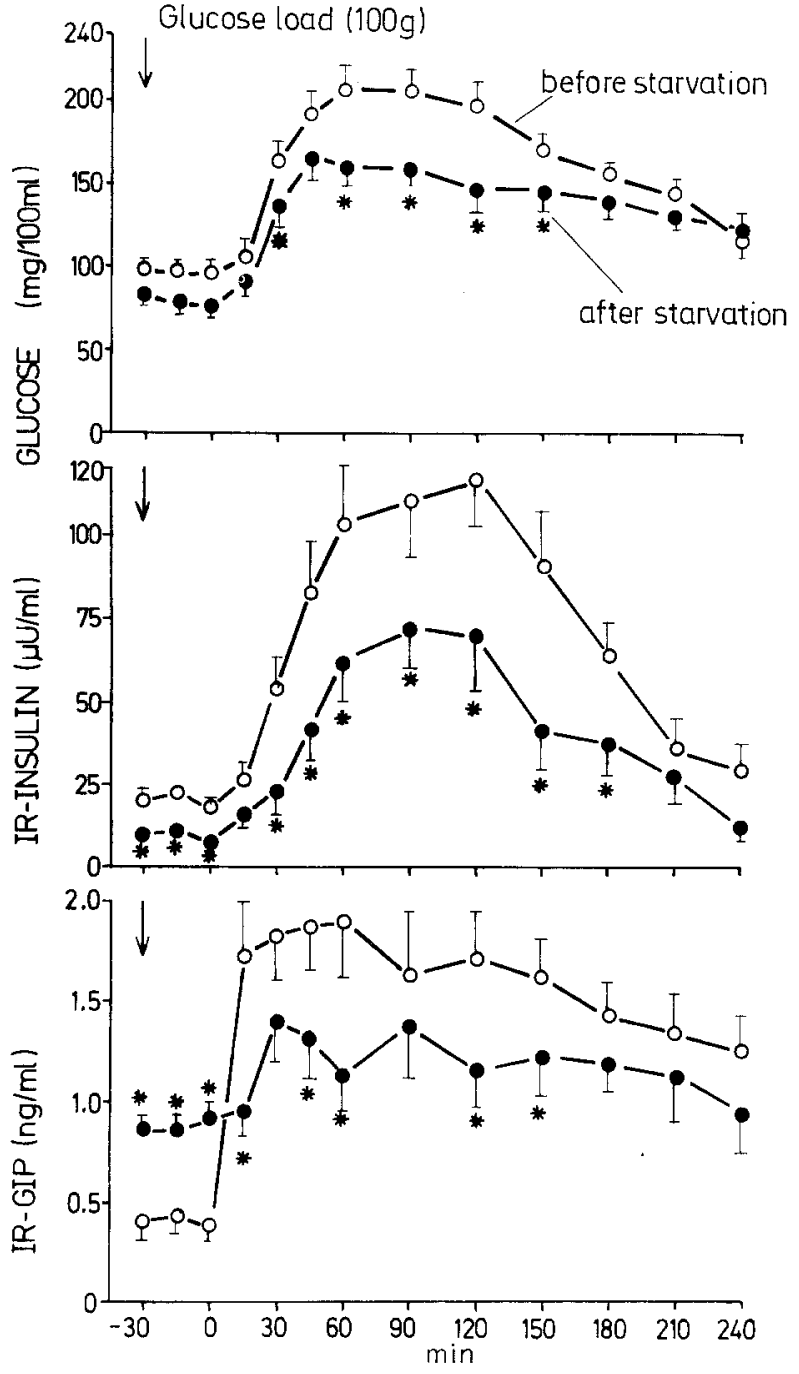

Fig. 3. Increase of serum levels of IR-GIP, IRI and glucose in 19 obese subjects with glucose intolerance before $\left(\mathrm{O}_{-} \mathrm{O}\right)$ and after $(\bullet-\bullet)$ starvation for 21 days and refeeding for three days. The subjects ingested $100 \mathrm{~g}$ glucose at $0 \mathrm{~min}$. All values are means \pm SEM. Significant differences between the serum levels before and after starvation are indicated $(*=p<0.02$ and less)

$30 \mathrm{~min}$ and remained so until the end of the test. The IRI increase occurred later than the IR-GIP increase. The difference between the two IRI curves was most marked between 90 and 240 min.

The glucose response was not different in the whole obese group before and after starvation (Fig. 2). However, this pattern changed when the obese patients were divided into subjects with nOGT and pOGT (Table 3). The glucose tolerance of the patients with nOGT deteriorated after starvation as demonstrated by a significantly larger integrated glucose response while the integrated glucose response of the obese patients with glucose intolerance tended to improve after starvation.

The integrated serum levels of IR-GIP and IRI were significantly smaller after starvation, both in obese subjects with nOGT and pOGT (Table 3 ).

\section{Response to an Oral Glucose Load before and after Starvation (Fig. 3, Table 3)}

The IR-GIP and IRI response to $100 \mathrm{~g}$ glucose ingestion was significantly smaller than to the test meal while the glucose response was similar (Fig. 3). Again, the IR-GIP response preceded the IRI increase.

After starvation the response of IR-GIP and glucose was significantly smaller during the first two hours after the glucose load. The pre- and post-starvation IRI levels were significantly different until the end of the test (4 hours).

The integrated serum levels of IR-GIP, IRI and glucose were significantly smaller after starvation (Table 3).

\section{Effect of Food Restriction on the Response to the Test Meal (Table 3)}

After food restriction for 21 days the augmented IRGIP release to a test meal of the obese subjects was significantly diminished. Simultaneously, the IRI response was smaller and the initial IRI peak occurred significantly earlier than before food restriction. Also the glucose tolerance was significantly improved.

The integrated response of IR-GIP and IRI was significantly smaller after food restriction. However, the values did not reach the post-starvation range (Table 3). The decrease of the integrated glucose response was not significant because the fasting glucose levels were also significantly lower after food restriction.

\section{Response to an Oral Triglyceride Load before and after Food Restriction (Table 3)}

The exaggerated response of IR-GIP to triglyceride ingestion in obesity was decreased significantly by a 3 week period of reduced caloric intake (Table 3 ). The integrated serum levels of IRI and glucose remained unchanged during fat ingestion before and after the hypocaloric diet.

\section{Effect of Food Restriction and Subsequent Starvation on the Response to the Test Meal (Table 3)}

In order to separate the effect of weight loss and food restriction a group of 14 obese subjects with pOGT reduced their caloric intake for 5 days, followed by complete starvation for 21 days. After 5 days of food 


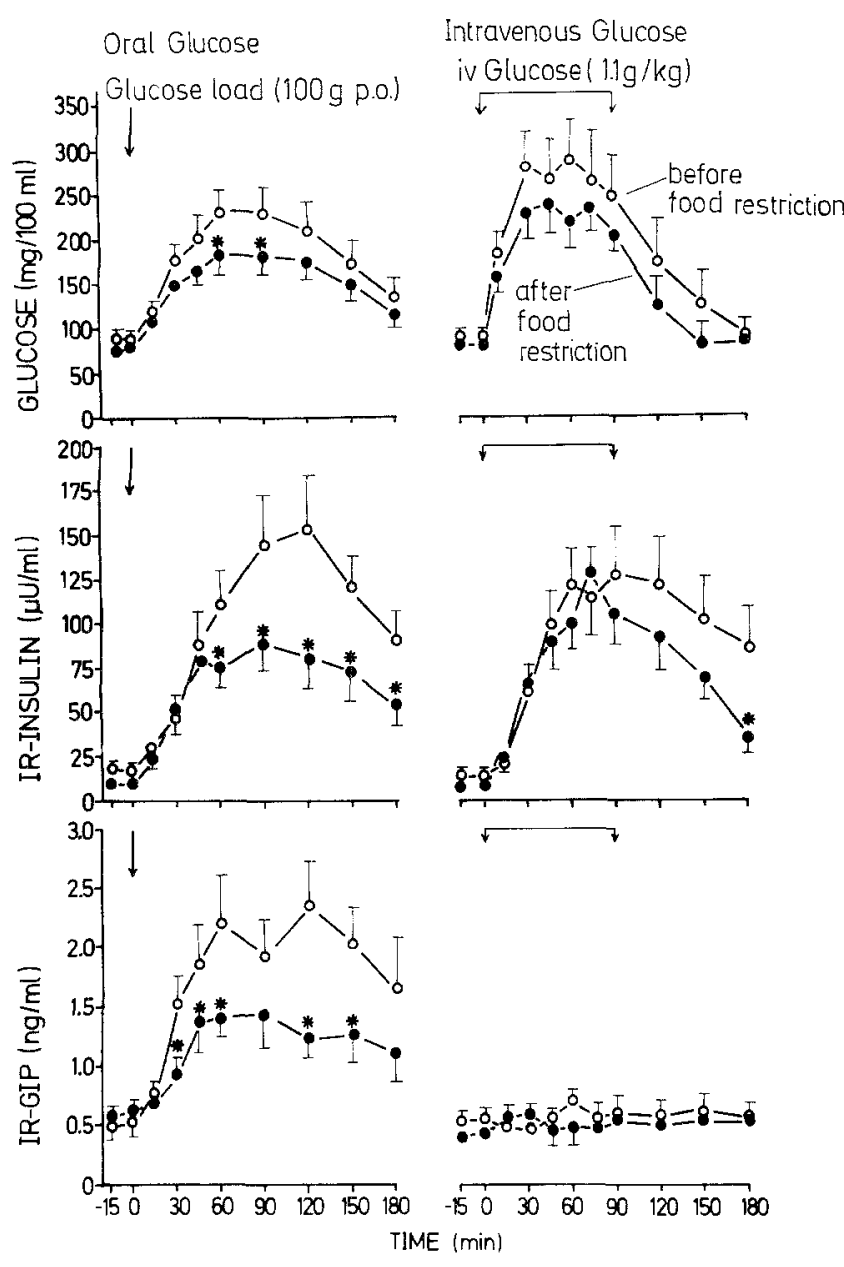

Fig. 4. Increase of serum levels of IR-GIP, IRI and glucose in 9 obese subjects with glucose intolerance following ingestion of $100 \mathrm{~g}$ glucose or intravenous infusion of $1.1 \mathrm{~g} / \mathrm{kg}$ body weight of glucose over $90 \mathrm{~min}$. The tests were repeated after reduced caloric intake for 14 days and one week unrestricted diet. All values are means \pm SEM. Significant differences between the serum levels before and after weight reduction of $5.2 \pm 0.7 \mathrm{~kg}(*=p<0.02$ and less) are indicated. $\bigcirc-\circ=$ before, $\bullet-\bullet=$ after weight reduction

restriction the integrated IR-GIP response was already significantly smaller and decreased further after the starvation period (Table 3 ). The integrated IRI levels did not significantly change after the short period of food restriction but did so after subsequent starvation.

In contrast, the glucose tolerance was already significantly improved after 5 days of food restriction but deteriorated again after starvation (Table 3 ).

\section{Comparison of Oral and Intravenous} Glucose Load before and after Food Restriction (Fig. 4, Table 3)

The IR-GIP, IRI and glucose responses to an oral (100 g glucose) and intravenous $(1.1 \mathrm{~g}$ glucose $/ \mathrm{kg}$ body weight over $90 \mathrm{~min}$.) glucose load were compared before and after 14 days of restricted food intake in 9 obese subjects with glucose intolerance. The weight loss at the time of the second test was 5.9 $\pm 0.5 \mathrm{~kg}$. The IR-GIP response after oral glucose was significantly decreased after food restriction. After intravenous glucose the IR-GIP levels did not change (Fig. 4).

The IRI response after oral glucose load was significantly smaller after food restriction while the IRI response to intravenous glucose did not differ between the tests before and after weight reduction. Only at the end of the experiment $(180 \mathrm{~min})$ the IRI levels were significantly lower during the second test (Fig. 4). The glucose increase after oral and intravenous glucose load was smaller after weight reduction.

The integrated responses are listed in Table 3. The integrated IR-GIP and IRI responses to oral glucose load were significantly smaller after $5.9 \pm 0.5 \mathrm{~kg}$ weight reduction while the responses to intravenous glucose remained unchanged.

The integrated glucose responses were significantly smaller after food restriction both to the oral and the intravenous glucose load.

It is noteworthy that the integrated IRI response to oral glucose load of obese subjects after food restriction decreased into the range of normal weight persons $(6.4 \pm 0.8 \mathrm{mU} / \mathrm{ml} .180 \mathrm{~min}$.) without complete normalisation of the glucose tolerance while the exaggerated IRI response of the same subjects to IV glucose infusion did not change after food restriction i. e. remained four times higher than in normal controls $(3.0 \pm 0.4 \mathrm{mU} / \mathrm{ml} .180 \mathrm{~min}$. $)$

\section{Discussion}

\section{Increase of Basal IR-GIP Levels During Starvation}

The increase of basal IR-GIP levels during starvation to levels close to the very high fasting levels of untreated juvenile diabetics [27] could be explained by the simultaneous fall of serum IRI levels and would suggest a feedback control between GIP and insulin in the fasting state. However, after food restriction for three weeks which also lead to weight reduction and an identical decrease of serum IRI levels the fasting GIP levels did not increase significantly. Therefore, the IR-GIP increase during starvation remains unexplained. A stimulatory effect of ketone bodies on the GIP producing cells is possible because ketone bodies are elevated during total starvation (but not food restriction) as well as in untreated juvenile diabetics. 


\section{Reversal of the Exaggerated IR-GIP Response in Obese Subjects}

The exaggerated IR-GIP response of obese subjects to oral ingestion of a test meal, glucose or fat [13] can be reversed by dietary means. Simultaneously, the exaggerated IRI response of obese subjects is reduced.

A decrease of the IRI response to glucose load after weight reduction of obese subjects $[1,2,3]$ and the development of hyperinsulinaemia by overeating in normal weight persons $[5,6]$ are well established. However, the mechanism involved is not yet understood. An overactive entero-insular axis has been suggested to participate in the hyperinsulinaemia of obesity [13]. The reversal of both, the IR-GIP and IRI responses after reduction of food intake shown in this study supports this contention.

Total starvation for 3 weeks with refeeding for three days had nearly the same effect as 3 weeks food restriction. Already food restriction for 5 days leading to a weight reduction of only $2.4 \mathrm{~kg}$, significantly changed the exaggerated GIP response. Therefore, partial mucosal atrophy as described after total starvation cannot be responsible for this effect.

After 3 weeks starvation or food restriction no correlation existed between the remaining overweight and the degree of normalisation of the GIP response. Two explanations for this may be discussed.

A negative feedback control between serum IRI levels and GIP secretion has been suggested [7, 8, $10]$. Evidence has been presented that this feedback control of GIP release by insulin is defective in obesity [13]. Since food restriction improves the insulin action and decreases the wellknown insulin resistance of obesity [4], it is conceivable that the inhibitory effect of insulin on the GIP producing cells is restored after reduced caloric intake.

However, this would not explain that the augmented IR-GIP response to oral fat is also reversed by food reduction because fat does not release insulin. It appears that the food restriction as such is critical for GIP secretion. Obviously, the GIP cells of the gut rapidly adapt to the quantity of the incoming load. Nothing is known about the mechanism of this adaptation of the GIP cells to dietary changes. A decrease in the number of GIP producing cells is unlikely, since the augmented IR-GIP response is reversed by caloric restriction in a few days. It has been concluded that the release of GIP is triggered by the process of absorption [17]. Dietary changes have been shown to produce adaptive responses in the activities of jejunal carbohydratemetabolising enzymes [21]. However, in this study the percentage of calories derived from carbohydrates was unchanged during the period of hypocaloric diet. Only the total amount of food intake, i. e. the load had been altered.

\section{Changes in IRI Response and Glucose Tolerance after Food Restriction}

It has been suggested that excessive nutrient ingestion promotes islet cell hyperplasia and hyperinsulinaemia and induces compensatory peripheral insulin resistance in obesity [22]. Evidence has been provided that the stimulatory effect of food is mediated via an exaggerated GIP secretion [13]. In accordance with this the increased IRI response of the obese subjects is normalised after food restriction in all instances in which the IR-GIP response to the test meal or to glucose load returned to normal independent of the amount of weight reduction. If the IRGIP response was only reduced but not normalised as after 5 days food restriction (protocol 5) the IRI release remained abnormal (Table 3). Another exception was the unchanged IRI release after triglycerides (protocol 4). In this experiment only the GIP response significantly improved while an IRI and glucose increase occurred neither before nor after food restriction.

The dependence of the reduced IRI response from the change in IR-GIP increase is best illustrated by the different IRI response to oral and IV glucose load after food restriction in obese subjects (protocol 6): While the IR-GIP and IRI response after oral glucose load became normal the IRI response to IV glucose was not significantly changed by weight reduction. This is understandable, because no IRGIP release occurs after IV glucose injection before or after food restriction. Thus, the IRI response to IV glucose indicates that the secretory capacity of the Bcells is not changed by 2 weeks food restriction while the IRI response to oral glucose load is dependent on the release of intestinal factors such as GIP.

Taking together the experimental proof that IRGIP is a glucose dependent insulinotropic hormone $[7,9,11,12]$ with the present observations it is reasonable to link IR-GIP and IRI release together. However this apparent association is not necessarily a causal one. The missing correlation between IRGIP and IRI before and after food restriction is due to the complexity of the system which makes analysis difficult. The net effect of the IR-GIP and IRI release is the result of at least the following factors: quantity and quality of the oral load, integrity of feedback control, amount and integrity of islet tissue (hyperplastic as described in obesity [23] or hypo- 
plastic as found in diabetes mellitus [28]), dietary regime before the test, glucose tolerance.

The changes in the glucose tolerance after starvation or food restriction did not closely follow the changes in the IRI response. However, these discrepancies depend mainly on the individual glucose tolerance before the experiment. It is well established that following starvation the glucose tolerance of obese subjects with normal glucose tolerance deteriorates while in obesity with glucose intolerance the glucose tolerance improves or becomes normal $[24,25,26]$.

It is concluded that the hypersecretion of GIP of obese subjects is reversed by fasting or food restriction and that this effect is accompanied by a decreased insulin response. This finding could support the view that GIP is important in the pathogenesis of the hyperinsulinaemia in obesity.

Acknowledgement. The authors thank Dr. J. C. Brown, Vancouver, for the generous supply of GIP antiserum and purified porcine GIP. They also acknowledge their gratitude for many stimulating discussions. In fact, some of the studies were commenced together with Dr. Brown during his stay in Göttingen 1974-1975. The authors also want to thank Mrs. K. Illmer and Mrs. B. Hillebrecht for their expert technical assistance. This work was supported by the Deutsche Forschungsgemeinschaft, BonnBad Godesberg, grant Cr 20/7 [12].

\section{References}

1. Kalkhoff, R. K., Kim, H. J., Cerletty, J., Ferrou, C. A.: Metabolic effects of weight loss in obese subjects. Changes in plasma substrate levels, insulin and growth hormone responses. Diabetes 20, 83-91 (1971)

2. Farrant, P. C., Neville, R. W. J., Stewart, G. A.: Insulin releasc in response to oral glucose in obesity: The effect of reduction of body weight. Diabetologia 5, 198-200 (1969)

3. Bagdade, J.D., Porte, Jr., D., Brunzell, J. D., Bierman, E. L.: Basal and stimulated hyperinsulinism: reversible metabolic sequelae of obesity. J. Lab. Clin. Med. 83, 563-569 (1974)

4. Bar, R. S., Gordon, P., Roth, J., Kahn, R., De Meyts, P.: Fluctuations in the affinity and concentration of insulin receptors on circulating monocytes of obese patients. Effects of starvation, refeeding, and dieting. J. Clin. Invest. 58, 1123-1135 (1976)

5. Sims, E. A. H., Danforth, E., Horton, E. S., Bray, G. A., Glennon, J.A., Salans, L.B.: Endocrine and metabolic effects of experimental obesity in man. Recent Prog. Horm. Res. 29, 457-496 (1973)

6. Mahler, R. J.: The relationship between eating and obesity. Acta Diabetol. Lat. 9 [suppl. 1], 449-465 (1972)

7. Brown, J. C., Dryburgh, J. R., Ross, S. A., Dupré, J.: Identification and actions of gastric inhibitory polypeptide. Recent Prog. Horm. Res. 31, 487-532 (1975)

8. Cleator, J. G. M., Gourlay, R. H.: Release of immunoreactive gastric inhibitory polypeptide (IR-GIP) by oral ingestion of food substances. Am. J. Surg. 130, 128-135 (1975)

9. Pederson. R. A., Schubert, H. E., Brown, J. C.: Gastric inhibitory polypeptide. Its physiologic release and insulinotropic action in the dog. Diabetes 24, 1050-1056 (1975)

10. Crockett, S.E., Cataland, S., Falko, J.M., Mazzaferri, E. L.: The insulinotropic effect of endogenous gastric inhibitory polypeptide in normal subjects. J. Clin. Endocrinol. Metab. 42, 1098-1103 (1976)

11. Schauder, P., Brown, J. C., Frerichs, H., Creutzfeldt, W.: Gastric inhibitory polypeptide: effect on glucose-induced insulin release from isolated rat pancreatic islets in vitro. Diabetologia 11, 483-484 (1975)

12. Pederson, R.A., Brown, J.C.: The insulinotropic action of gastric inhibitory polypeptide in the perfused isolated rat pancreas. Endocrinology 99, 780-785 (1976)

13. Creutzfeldt, W., Ebert, R., Willms, B., Frerichs, H., Brown, J. C.: Gastric inhibitory polypeptide (GIP) and insulin in obesity: Increased response to stimulation and defective feedback control of serum levels. Diabetologia 14, 15-24 (1978)

14. Ebert, R., Willms, B., Brown, J.C., Creutzfeldt, W.: Serum gastric inhibitory polypeptide (GIP) levels in obese subjects and after weight reduction. Eur. J. Clin. Invest. 6, 327 (1976)

15. Köbberling, J., Creutzfeldt, W.: Comparison of different methods for the evaluation of the oral glucose tolerance test. Diabetes 19, 870-877 (1970)

16. Documenta Geigy Scientific Tables, 6th ed., p. 624. Manchester: Geigy 1962

17. Creutzfeldt, W., Ebert, R., Arnold, R., Frerichs, H., Brown, J. C.: Gastric inhibitory polypeptide (GIP), gastrin, and insulin: response to test meal in coeliac disease and after duodenopancreatectomy. Diabetologia 12, 279-286 (1976)

18. Mclani, F., Ditschuncit, H., Bartelt, K. M., Friedrich, H., Pfeiffer, E.F.: Über die radioimmunologische Bestimmung von Insulin im Blut. Klin. Wochenschr. 43, 1000-1007 (1965)

19. Kuzio, M., Dryburgh, J.R., Malloy, K.M., Brown, J.C.: Radioimmunoassay for gastric inhibitory polypeptide. Gastroenterology 66, 357-364 (1974)

20. Stern, D.H., Walsh, J.H.: Gastrin release in postoperative ulcer patients: evidence for release of duodenal gastrin. Gastroenterology 64, 363-369 (1973)

21. Rosensweig, N.S., Stifel, F.B., Herman, R.H., Zakim, D.: The dietary regulation of the glycolytic enzymes. II. Adaptive changes in human jejunum. Biochim. Biophys. Acta 170, 228-234 (1968)

22. Grey, N. J., Kipnis, D.M.: Effect of diet composition on the hyperinsulinemia of obesity. N. Engl. J. Med. 285, 827-831 (1971)

23. Ogilvie, R.: Sugar tolerance in obese subjects: a review of 65 cases. Q. J. Med. 28, 345-358 (1935)

24. Jackson, I.M.D., McKiddie, P.T., Buchanan, K.D.: The effect of prolonged fasting on carbohydrate metabolism: Evidence of heterogenicity in obesity. J. Endocrinol. 40, 259-260 (1968)

25. Tzagournis, M., Skillman, T. G.: Glucose intolerance mechanisms after starvation. Metabolism 19, 170-178 (1970)

26. Jackson, R. A., Moloney, M., Lowy, C., Wright, A. D., Hartog, M., Pilkington, T.R.E., Fraser, T. R.: Differences between metabolic responses to fasting in obese diabetic and obese nondiabetic subjects. Diabetes 20, 214-227 (1971)

27. Ebert, R., Frerichs, H., Creutzfeldt, W.: Serum gastric inhibitory polypeptide (GIP) response in patients with maturity onset diabetes and in juvenile diabetes. Diabetologia 12, 388 (1976)

28. Gepts, W.: Contribution à l'étude morphologique des îlots de Langerhans au cours du diabètes. Bruxelles: Les éditions "Acta Medica belgica" 1957

Received: October 13, 1977,

and in revised form: January 23, 1978

Prof. Dr. med. W. Creutzfeldt

Medizinische Universitätsklinik

Robert-Koch-Straße 40

D-3400 Göttingen

Federal Republic of Germany 